\title{
PENERAPAN METODE PROFILE MATCHING PADA SISTEM PENDUKUNG KEPUTUSAN PERFORMA PRODUKSI BURUNG PUYUH
}

\author{
${ }^{[1]}$ Riska Dhenabayu, ${ }^{[2]}$ Ahmad Zainudin \\ ${ }^{[1],[2]}$ Universitas Islam Balitar Blitar
}

\begin{abstract}
Penetasan telur burung puyuh dapat dilakukan dengan dua cara, yaitu alami dan buatan. Alami artinya telur burung puyuh dierami langsung oleh induknya. Sedangkan cara buatan artinya telur burung puyuh ditetaskan dengan bantuan mesin tetas. Tujuan dari penelitian ini adalah merancang, mengimplementasi, dan menguji sistem pendukung keputusan performa produksi burung puyuh dengan metode profile matching. Metode profil matching adalah metode yang mengasumsikan bahwa subyek yang diteliti harus memenuhi tingkat variabel prediksi ideal bukan tingkat minimal.Terdapat tiga spek yang digunakan dalam menentukan performa produksi burung puyuh. Aspek tersebut adalah genetik, ransum pakan, dan lingkungan. Hasil dari penelitian ini adalah aplikasi yang dibangun dapat membantu, mempercepat,dan mempermudah proses pengambilan keputusan performa produksi burung puyuh. Selain itu, aplikasi yang dibangun mudah digunakan.
\end{abstract}

Kata kunci : Decision Support System, Profile Matching, Production Performance of Quails.

\section{Pendahuluan}

Banyaknya petani yang membudidayakan burung puyuh maka semakin banyak juga kebutuhan dalam usaha untuk mengembangbiakkan puyuh tersebut. Semakin banyak juga waktu yang dibutuhkan dalammenentukan telur puyuh yang memenuhi kriteria untuk dikembangbiakkan ataupun ditetaskan, ada dua model atau cara dalam penetasan telur puyuh yaitu dengan cara alami yang dilakukan oleh induk puyuh langsung dan secara buatan dengan bantuan mesin tetas. Menurut Direktorat Jenderal Peternakan Dan Kesehatan Hewan (DITJENNAK) Kementrian Pertanian Indonesia tahun 2015, pada bukunya dijelaskan dari tahun 2011 sampai dengan 2015 terjadi peningkatan pada populasi ternak burung puyuh, tercatat 7.357 populasi pada tahun 2011 dan 12.904 populasi pada tahun 2015 .

Burung Puyuh merupakan salah satu jenis unggas yang cukup produktif untuk menghasilkan telur, disamping itu dagingnya cukup lezat untuk dikonsumsi sebagai sumber protein. Salah satu faktor yang dapat menentukan keberhasilan kegiatan beternak puyuh adalah keberadaan bibit unggul. Hal tersebut nantinya akan behubungan dengan hasil dan kualitas dari penetasan dan pembibitan burung puyuh (Achmanu, dkk, 2015). 
Kualitas penetasan yang baik erat hubugannya dengan perkawinan yang baik sehingga menghasilkan telur yang fertil. Pada umumnya perkawinan pada pembibitan burung puyuh memakai imbangan jantan-betina 1:2-4. Perkawinan burung puyuh perlu dipertimbangkan imbangan jangan-betina yang tepat. Karena hal ini menyangkut efisiensi dan efektifitas penggunaan pejantan terhadap betina agar diperoleh hasil yang optimal, terutama apabila diterapkan pada peternakan pembibitan. Lantai kandang dalam pembibitan puyuh juga menjadi faktor penting. Penentuan lantai kandang perlu diperhatikan agar puyuh dapat merasa lebih nyaman, karena kandang adalah lingkungan terkecil tempat puyuh hidup dan berproduksi. Sehingga upaya untuk memberikan kondisi yang baik dan nyaman bagi puyuh akan berimbas pada hasil produksi yang tinggi (Abidin, 2002).

Listiyowati dan Roospitasari (2009) menyatakan bila betina terlalu banyak maka dikhawatirkan banyak telur yang kosong (infertile), karena induk jantan tidak dapat mengawini seluruh induk betina.

Metode pemilihan telur puyuh yang digunakan saat ini adalah memilih telur puyuh yang sudah ada dengan memperhatikan bentuk fisik telur secara langsung. Kelemahan dari metode tersebut adalah memerlukan waktu yang lama untuk menentukan pilihan telur puyuh yang sesuai dengan kriteria yang diinginkan dan harus menunggu burung puyuh bertelur terlebih dahulu.

Berdasarkan latar belakang di atas,maka dalam penelitian ini dibuat suatu Sistem Pendukung Keputusan (SPK) dengan menggunakan metode Profile Matching untuk membantu dalam pengambilan keputusan performa produksi burung puyuh. Profile Matchingatau pencocokan profil adalah metode yang sering digunakan sebagai mekanisme dalam pengambilan keputusan dengan mengamsusikan bahwa terdapat tingkat variable predictor yang ideal yang harus dipenuhi oleh subyek yang diteliti, bukannya tingkat minimal yang harus dipenuhi atau dilewati (Kusrini, 2007).

\section{Metode Penelitian}

\section{A. Waktu dan Tempat Penelitian}

Penelitian dilakukan di peternakan Kidung Asmara milik bapak Anang Widigdyo dari Dusun Kedungrejo Desa Salamrejo Kecamatan Binangun Kabupaten Blitar, pada tanggal 1 - 30 April 2017.

\section{B. Metode Penelitian}

\section{MetodeProfile Matching (PM)}

Menurut Kusrini (2007) metode profile matchingatau pencocokan profil adalah metode yang sering digunakan sebagai mekanisme dalam pengambilan keputusan dengan mengamsusikan bahwa terdapat tingkat variable predictor yang ideal yang harus dipenuhi oleh subyek yang diteliti, bukannya tingkat minimal yang harus dipenuhi atau dilewati. Dalam proses profile matchingsecara garis besar merupakan 
proses membandingkan atara nilai data aktual dari suatu profil yang akan dinilai dengan ilia profil yang diharapkan, sehingga dapat diketahui perbedaan kompetensinya (disebut juga gap), semakin kecil gap yang dihasilkan maka bobot nilainya semakin besar. Ada beberapa tahap dalam perhitungan ProfileMatching, yaitu:

\section{a. Penentuan Aspek}

Penentuan aspek digunakan untuk menentukan aspek-aspek yang berpengaruh dalam penentuan telur puyuh berkualitas.

\section{b. Pemetaan Gap}

Gap adalah perbedaan antara profil yang dimiliki oleh masing-masing alternatif dengan profil standar yang ditentukan oleh sistem.

Gap = attributevalue-targetvalue

Keterangan rumus (1), pada penelitian ini attributevalue adalah nilai awal populasi burung puyuh, dan targetvalue adalah nilai target populasiburung puyuh, nilai target didapatkan dari hasil wawancara pihak peternakan Kidung Asmara.

\section{c. Perhitungan Gap}

Perhitungan gapadalah melakukan sesuai dengan aspek yang sudah ditentukan menggunakan rumus (1).

\section{d. Pembobotan}

Tahap ini akan ditentukan bobot nilai masing-masing aspek dengan menggunakan bobot nilai yang telah ditentukan bagi masing-masing aspek itu sendiri. Adapun inputan dari proses pembobotan ini adalah selisih dari nilai awal populasi burung puyuh dan nilai target.

TABEL 1

BobOT NilAi GAP

\begin{tabular}{cccc} 
No & Selisih & Nilai Bobot & Keterangan \\
\hline $\mathbf{1}$ & 0 & 5 & Kompetensi sesuai dengan yang dibutuhkan \\
\hline $\mathbf{2}$ & 1 & 4,5 & Kompetensi individu kelebihan 1 tingkat/level \\
\hline $\mathbf{3}$ & -1 & 4 & Kompetensi individu kurang 1 tingkat/level \\
\hline $\mathbf{4}$ & 2 & 3,5 & Kompetensi individu kelebihan 2 tingkat/level \\
\hline $\mathbf{5}$ & -2 & 3 & Kompetensi individu kurang 2 tingkat/level \\
\hline $\mathbf{6}$ & 3 & 2,5 & Kompetensi individu kelebihan 3 tingkat/level \\
\hline $\mathbf{7}$ & -3 & 2 & Kompetensi individu kurang 1 tingkat/level \\
\hline $\mathbf{8}$ & 4 & 1,5 & Kompetensi individu kelebihan 4 tingkat/level \\
\hline $\mathbf{9}$ & -4 & 1 & Kompetensi individu kurang 4 tingkat/level \\
& & & (Sumber: kusrini, 2007)
\end{tabular}




\section{e. Perhitungan dan pengelompokan CoreFactor dan SecondaryFactor}

Tahap selanjutnya adalah perhitungan Core Factor dan Secondary Factor. Core Factor adalah nilai dengan prioritas lebih tinggi pada sub aspek, dan Secondary Factor adalah sub aspek yang mempunyai nilai lebih rendah daripada Core Factor.

Persamaan untuk perhitungan Core Factor dapat ditulis seperti berikut:

$$
\mathrm{NCF}=\frac{\sum N C(a, b, c)}{\sum I C}
$$

Dimana:

$$
\begin{array}{ll}
\mathrm{NCF} & =\text { Nilai rata-rata Core Factor } \\
\mathrm{NC} & =\text { Jumlah total nilai Core Factor } \\
\mathrm{a}, \mathrm{b}, \mathrm{c} & =\text { Aspek } \\
\mathrm{IC} & =\text { Jumlah item Core Factor }
\end{array}
$$

Sementara itu persamaan untuk menghitung secondary factor adalah sebagai berikut:

$$
\mathrm{NSF}=\frac{\sum N S(a, b, c)}{\sum I S}
$$

Dimana:

$$
\begin{array}{ll}
\text { NSF } & =\text { Nilai rata-rata Secondary Factor } \\
\text { NS } & =\text { Jumlah total nilai Secondary Factor } \\
\text { a,b,c } & =\text { Aspek } \\
\text { IS } & =\text { Jumlah item Secondary Factor }
\end{array}
$$

\section{f. Perhitungan Nilai Total}

Selanjutnya adalah menghitung nilai total berdasarkan prosentase CoreFactor dan Secondary Factoryang diperkirakan berpengaruh terhadap hasil setiap profil dengan menggunakan persaman sebagai berikut:

$$
\begin{array}{cc}
\mathbf{N}(\mathbf{a}, \mathbf{b}, \mathbf{c})=(\mathbf{x}) \% * \mathbf{N C F}(\mathbf{a}, \mathbf{b}, \mathbf{c})+(\mathbf{x}) \% * \mathbf{N S F}(\mathbf{a}, \mathbf{b}, \mathbf{c}) \ldots . . . . . \\
\begin{array}{cc}
\text { Dimana: } & \text { Nilai rata-rata Core Factor } \\
\mathrm{NCF}(\mathrm{a}, \mathrm{b}, \mathrm{c}) & =\text { Nilai rata-rata Secondary Factor } \\
\mathrm{NSF}(\mathrm{a}, \mathrm{b}, \mathrm{c}) & =\text { Nilai total dari aspek } \\
\mathrm{N}(\mathrm{a}, \mathrm{b}, \mathrm{c}) & \text { Nilai persen yang dimasukkan } \\
\mathrm{X}(\%) &
\end{array}
\end{array}
$$

\section{g. Perhitungan Ranking}

Tahap akhir dari proses Profile Macthing adalah melakukang perhitunganrangking dari sampel telur puyuh, dengan menggunakan persamaan sebagai berikut:

$$
\text { Rank }=(\mathbf{x}) \% * \mathbf{N}(\mathbf{a})+(\mathbf{x}) \% * \mathbf{N}(\mathbf{b})+(\mathbf{x}) \% * \mathbf{N}(\mathbf{c})
$$

Dimana:

$$
\begin{array}{ll}
\mathrm{N}(\mathrm{a}) & =\text { Nilai total dari aspek (a) } \\
\mathrm{N}(\mathrm{b}) & =\text { Nilai total dari aspek (b) } \\
\mathrm{N}(\mathrm{c}) & =\text { Nilai total dari aspek (c) } \\
(\mathrm{x}) \% & =\text { Nilai persen yang dimasukkan }
\end{array}
$$




\section{Diagram Konteks}

Diagram Konteks adalah bagian yang menggambarkan sumber serta tujuan data yang akan diproses atau dengan kata lain diagram tersebut digunakan untuk menggambarkan sistem secara umum/global dari keseluruansistem yang ada (Jogiyanto, 2001).

Berikut ini adalah Diagram Konteks dari SPK Performa Produksi Burung Puyuh yang ditunjukkan pada gambar 2.

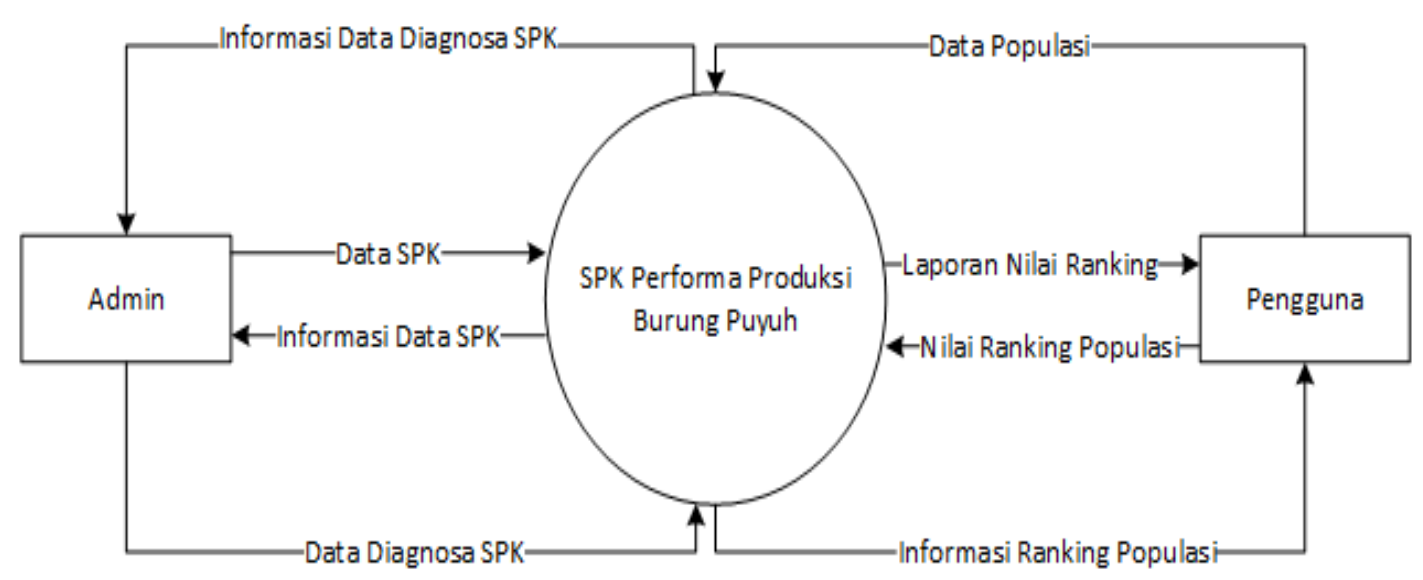

Gambar 2. Diagram Konteks

Rancangan diagram konteks yang ditujukkan pada gambar 3.1 dijelaskan, terdapat dua terminator/entitas yaitu Admin dan Pengguna. Admin berperan sebagai pembuat sistem dimana data-data akurat yang sudah didapatkan diolah menjadi sebuah sistem pendukung keputusan, admin juga dapat melakukan diaognosa sistem untuk mengetahui perkembangan sistem yang sudah buat. Pengguna adalah operator yang hanya bisa mengakses SPK dan mengetahui hasil dari perhitunganya, operator tidak dapat mengubah isi data SPK.

\section{Data Flow Diagram (DFD)}

DFD level 1 adalah diagram yang menjabarkan lebih detail proses yang ada pada DFD level 0 (Diagram Konteks) dari gambar 2. 


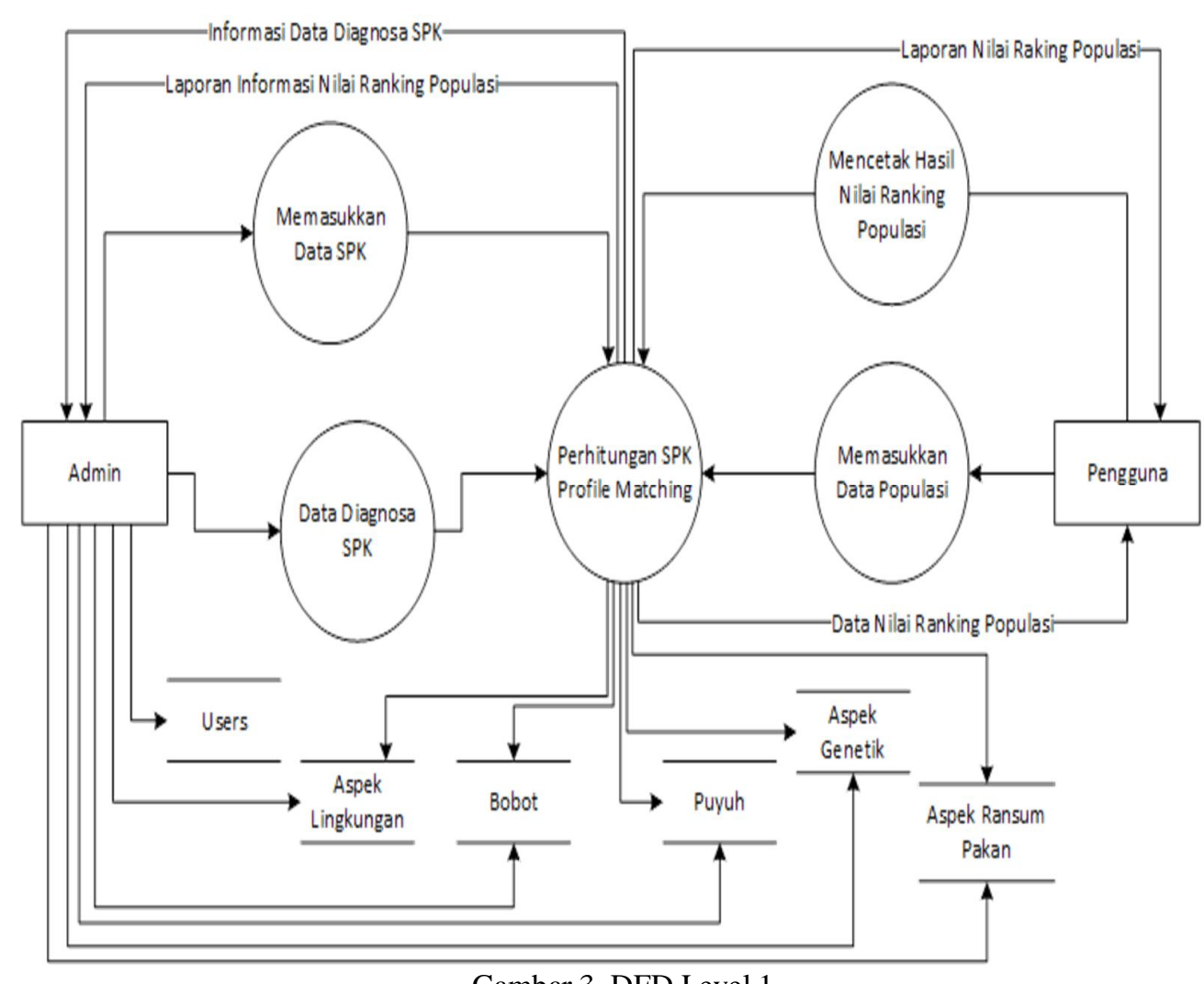

Seperti yang sudah dijelaskan sebelumnya bahwa DFD level 1 adalah penjabaran dari rancangan diagram konteks yang ditunjukkan pada gambar 3.1. Admin dapat mengakses kedalam keseluruhan sistem, semetara pengguna biasa atau operator hanya dapat mengakses aplikasi spk saja.

\section{Flowchart}

Flowchart adalah diagram yang menunjukkan alir di dalam program atau prosedur sistem secara logika (Jogiyanto, 2001).

a. Flowchart Sistem

Flowchart sistem menunjukkan gambaran umum alir sistem berjalan. 


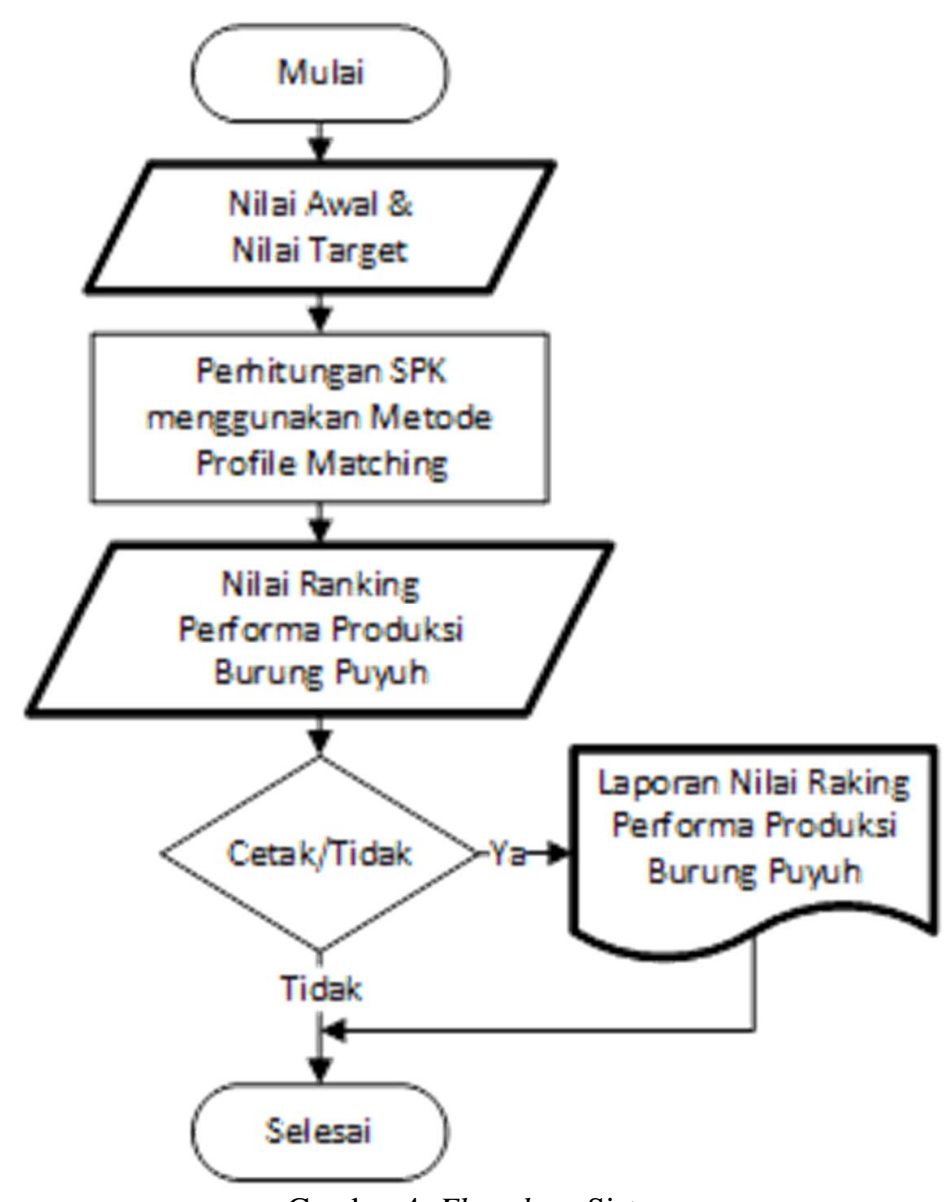

Gambar 4. Flowchart Sistem

Penjelasan gambar 4 dimulai dengan menginputkan nilai awal dan nilai target populasi puyuh maka sistem akan melakukan proses perhitungan performa produksi burung puyuh menggunakan metode profile matching, setelah dilakukan perhitungan maka output atau kelaurannya adalah ranking performa produksi burung puyuh, pengguna dapat mencetak hasil perhitungan jika tidak maka sistem selesai.

b. Flowchart Program

Flowchart program menggambarkan alir pada perhitungan metode profile matching. 


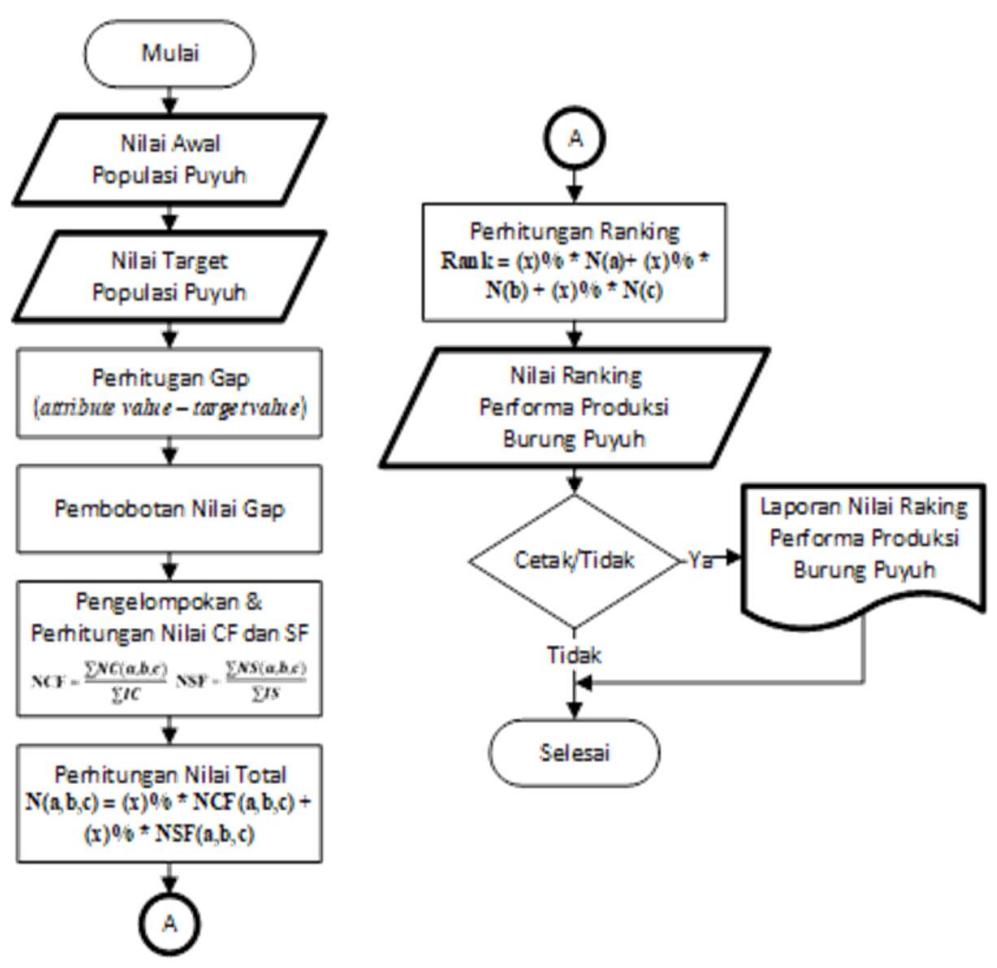

Gambar 5. Flowchart Program

Penjelasan gambar 5 dimulai dengan menginputkan nilai awal dan nilai target populasi puyuh lalu secara otomatis aplikasi akan menghitung gap yang diperoleh, proses selanjutnya proses pembobotan dari nilai gap yang di peroleh, lalu proses selanjutnya pengelompokan dan perhitungan core factor dan secondary factor tiap aspek populasi dan dilanjut dengan proses perhitungan nilai total dari tiap aspek, setelah itu perhitungan ranking dengan menjumlahkan nilai total tiap aspek, maka akan tanilai ranking tiap aspek sebagai keluaran, jika pengguna ingin mencetak hasil maka akan mendapatkan laporan nilai ranking dan jika pengguna tidak ingin mencetak hasil nilai maka selesai.

\section{Hasil Dan Pembahasan}

\section{A. Antar Muka Aplikasi}

Teknologi yang digunakan dalam pengembangan sistem ini adalah teknologi aplikasi berbasis web. Aplikasi berbasis web dapat membentuk sebuah program yang berdiri sendiri dan dapat dijalankan dalam lingkungan internet. Sehingga dimanapun pengguna (user) berada dapat menggunakan aplikasi ini dengan mengakses situs tersebut secara cepat dan mudah. Dengan sistem web basedini diharapkan dapat memberikan kemudahan kepada pemilik peternakan dalam menentukan performa produksi burung puyuh. 
Proses pengaplikasian dari sistem ini membutuhkan beberapa komponen pendukung yang sudah terpasang (installed) pada perangkat komputer maupun laptop pengguna seperti XAMPP (control panel v3.2.2), web browser yang mendukung yaitu, Microsoft Edge, Mozila Firefox atau Google Chrome.

Berikut ini adalah tampilan dari aplikasi yang sudah dibuat:

a. Halaman Beranda

Halaman beranda adalah halaman yang akan pertama kali muncul ketika pengguna membuka aplikasi SPK, yang ditunjukkan pada gambar 6 berikut.
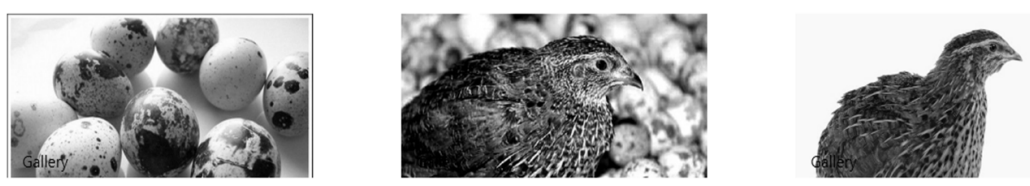

Gambar 6. Halaman Beranda

Gambar di atas terdapat beberapa menu dengan berbagai fungsi sebagai berikut:

1. Menu (dropdown) Aspek

Ada 3 submenu yang terdapat pada menu aspek, yaitu menu Aspek Genetik, Aspek Ransum Pakan dan Aspek Lingkungan.

2. Menu Perhitungan SPK

Halaman perhitungan SPK untuk melakukan analisa/perhitungan SPK performa produksi burung puyuh dengan menggunakan metode profile matching. Setelah pengguna selesai melakukan perhitungan maka pengguna bisa langsung mencentak hasil perhitungan tersebut. tahap pertama adalah dengan memasukkan nilai awal dan nilai target pada form Perhitungan Gap yang ditunjukkan pada gambar 7 .

\begin{tabular}{|c|c|c|c|c|c|c|c|c|c|}
\hline \multirow{2}{*}{ No } & \multirow{2}{*}{ Id Puyuh } & \multicolumn{3}{|c|}{ Aspek Genetik } & \multicolumn{2}{|c|}{ Aspek Ransum Pakan } & \multicolumn{3}{|c|}{ Aspek Lingkungan } \\
\hline & & Sub 1 & Sub 2 & Sub 3 & Sub 1 & Sub 2 & Sub 1 & Sub 2 & Sub 3 \\
\hline 1 & P01 & 4 & 4 & 3 & 3 & 4 & 4 & 4 & 4 \\
\hline 2 & P02 & 1 & 3 & 2 & 3 & 4 & 4 & 3 & 1 \\
\hline \multicolumn{2}{|c|}{ Nilai Target } & 2 & 3 & 1 & 1 & 1 & 1 & 2 & 4 \\
\hline
\end{tabular}

Gambar 7.Form Perhitungan Gap (Operator) 
P01 adalah kode Puyuh dalam satu populasi, untuk menghitung gappengguna haru memasukkan nilai awal dan nilai target, dengan keterangan:

a) Aspek Genetik

1) Sub $1=$ Umur Produksi

2) $\operatorname{Sub} 2=$ Berat Indukan

3) Sub $3=$ Perkawinan

b) Aspek Ransum Pakan

1) Sub $1=$ Bahan Pakan

2) Sub 2 = Tambahan Pakan

c) Aspek Lingkungan

1) Sub $1=$ Sanitasi Kandang

2) Sub $2=$ Suhu

3) Sub 3 = Kelembapan

Setelah pengguna memasukkan nilai awal populasi burung puyuh pada yang ditunjukkan pada gambar 7 maka sistem akan langsung menunjukkan hasil dari perhitungan terserbut yang ditunjukkan pada gambar 8 .

\begin{tabular}{|c|c|c|c|c|c|}
\hline \multirow{2}{*}{ No } & \multirow{2}{*}{ Id Puyuh } & \multicolumn{3}{|c|}{ Nilai Total } & \multirow{2}{*}{ Nilai Ranking } \\
\hline & & Aspek Genetik & Aspek Ransum Pakan & Aspek Lingkungan & \\
\hline 1 & P01 & 3.8 & 2.9001 & 3.650 & 3.5 \\
\hline 2 & $\mathrm{P} 02$ & 4.45 & 2.900 & 3.15 & 3.725 \\
\hline
\end{tabular}

Gambar 8. Form Nilai Ranking (Operator)

Gambar 8 menunjukkan hasil perhitungan ranking dari P01dan P02.

3. Enter (FormLogin)

Form Loginadalah from untuk admin agar bisa mengakses halaman admin untuk mengolah data.

Gambar 9 berikut ini adalah tampilan form login untuk admin.

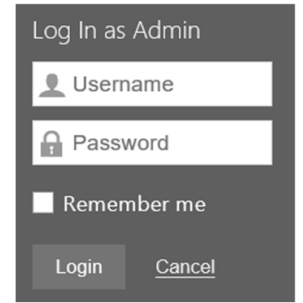

Gambar 9 - Form Login 


\section{Perhitungan Metode Profile Matching}

Perhitungan metode Profile Matching adalah penerapan Profile Matching untuk menentukan performa produksi burung puyuh, dalam kasus tersebut ada 3 aspek yang digunakan untuk penilaian, diantaranya:

a. Aspek Genetik
1) Umur Produksi
2) Berat Indukan
3) Perkawinan

b. Aspek Ransum Pakan

1) Bahan Pakan

2) Tambahan Pakan

c. Aspek Lingkungan

1) Sanitasi Kandang

2) Suhu

3) Kelembapan

Nilai target dapat ditentukan dari nilai ideal tiap sub aspek, tabel 3 berikut adalah tabel dari nilai target yang sudah didapat:

TABEL 3

NILAI TARGET

\begin{tabular}{ccccccccc}
\hline & \multicolumn{3}{c}{ Aspek Genetik } & \multicolumn{3}{c}{ Aspek Ransum Pakan } & \multicolumn{2}{c}{ Aspek Lingkungan } \\
\cline { 2 - 9 } & Sub 1 & Sub 2 & Sub 3 & Sub 1 & Sub 2 & Sub 1 & Sub 2 & Sub 3 \\
\hline Nilai Target & 2 & 3 & 1 & 1 & 1 & 1 & 2 & 4
\end{tabular}

Tahap Selanjutnya adalah perhitungan gap untuk tiap aspek menggunakan rumus (1). Nilai target yang digunakan pada penelitian ini untuk aspek genenik menggunakan nilai 2, 3 dan 1, pada aspek ransum pakan menggunakan nilai 1, 1 dan pada aspek lingkungan menggunakan nilai 1, 2, dan 4.

1. Perhitungan GapAspek Genetik

$$
\text { TABEL } 4
$$

GAP ASPEK GENETIK

Noo Id Puyuh 112

\begin{tabular}{llllll}
\hline $\mathbf{1}$ & P01 & 4 & 4 & 3 & \\
\hline & Nilai Target & $\mathbf{2}$ & $\mathbf{3}$ & $\mathbf{1}$ & \\
\hline $\mathbf{1}$ & P01 & 2 & 1 & 2 & Gap
\end{tabular}


2. Aspek Ransum Pakan

TABEL 5

GAP ASPEK RANSUM PAKAN

No Id Puyuh 112

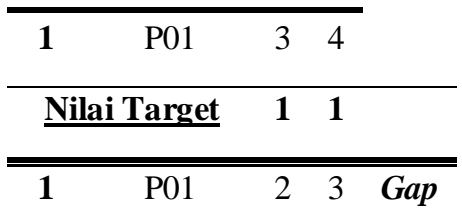

3. Aspek Lingkungan

TABEL 6

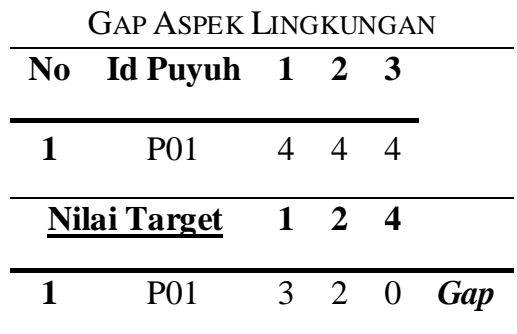

Setelah diperoleh gap pada setiap populasi, selanjutnya adalah pembobotan berdasarkan tabel 7

TABEL 7

\begin{tabular}{ccc} 
& \multicolumn{2}{c}{ NiLAi BoвOT } \\
No & Selisih & Nilai Bobot \\
\hline $\mathbf{1}$ & 0 & 5 \\
\hline $\mathbf{2}$ & 1 & 4,5 \\
\hline $\mathbf{3}$ & -1 & 4 \\
\hline $\mathbf{4}$ & 2 & 3,5 \\
\hline $\mathbf{5}$ & -2 & 3 \\
\hline $\mathbf{6}$ & 3 & 2,5 \\
\hline $\mathbf{7}$ & -3 & 2 \\
\hline $\mathbf{8}$ & 4 & 1,5 \\
\hline $\mathbf{9}$ & -4 & 1
\end{tabular}

Pada tabel 7 dijelaskan bahwa nilai selisih dan nilai bobot, semakin kecil selisihnya maka nilai bobot yang dihasilkan semakin besar. Dengan keterangan bobot CF adalah $60 \%$ dan SF $40 \%$. 
Hasilnya setiap aspek memiliki tabel pembobotan seperti berikut:

1. Aspek Genetik

TABEL 8

Pembobotan Nilai Aspek Genetik

\begin{tabular}{ccccc} 
No & Id Puyuh & $\mathbf{1}$ & $\mathbf{2}$ & $\mathbf{3}$ \\
\hline $\mathbf{1}$ & P01 & 2 & 1 & 2
\end{tabular}

Hasil Pembobotan

\begin{tabular}{lllll}
\hline 1 & P01 & 3.5 & 4.5 & 3.5
\end{tabular}

2. Aspek Ransum Pakan

TABEL 9

PEMbobotan Nilai ASPEK RANSUm PAKAN

\begin{tabular}{cccc}
\hline No & Id_Puyuh & $\mathbf{1}$ & $\mathbf{2}$ \\
\hline $\mathbf{1}$ & P01 & 2 & 3
\end{tabular}

\begin{tabular}{llll}
\hline \multicolumn{4}{c}{ Hasil Pembobotan } \\
\hline $\mathbf{1}$ & P01 & 3.5 & 2.5 \\
\hline
\end{tabular}

3. Aspek Lingkungan

TABEL 10

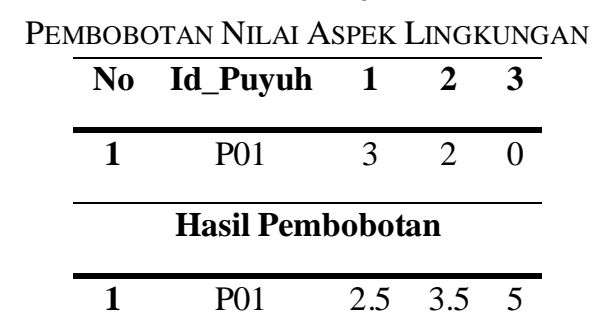

Pengelompokkan Core Factor pada aspek Genetik adalah pada sub aspek (b), dan (c), untuk Secondary Factoradalah sub aspek (a). Untuk pengelompokkan Core Factor pada aspek Ransum Pakan adalah pada sub aspek (b), dan (a) sebagai Secondary Factor. Dan pengelompokkan Core Factor untuk aspek Lingkungan adalah pada sub aspek (a) dan (c), untuk Secondary Factor adalah sub aspek (b).

Setelah didapatkan nilai pembobotan selanjutnya adalah perhitungan Core Factor dan Secondary Factor. Core Factor adalah nilai dengan prioritas lebih tinggi pada sub aspek, dan Secondary Factor adalah sub aspek yang mempunyai nilai lebih rendah daripada Core Factor, yang digunakan untuk menghitung $\mathrm{CF}$ menggunakan persamaan (2), untuk perhitungan SF menggunakan persamaan (3). 
1. Aspek Genetik

$$
\begin{aligned}
& \mathrm{NCF}=\frac{4.5+3.5}{2}=\frac{8}{2}=4 \\
& \mathrm{NSF}=\frac{3.5}{1}=3.5
\end{aligned}
$$

2. Aspek Ransum Pakan

$$
\begin{aligned}
& \mathrm{NCF}=\frac{2.5}{1}=2.5 \\
& \mathrm{NSF}=\frac{3.5}{1}=3.5
\end{aligned}
$$

3. Aspek Lingkungan

$$
\begin{aligned}
& \mathrm{NCF}=\frac{2.5+5}{2}=\frac{7.5}{2}=3.75 \\
& \mathrm{NSF}=\frac{3.5}{1}=3.5
\end{aligned}
$$

Tahap selanjutnya adalah menghitung nilai total berdasarkan prosentase CoreFactor dan Secondary Factor yang berpengaruh terhadap performa produksi burung puyuh dengan menggunakan persaman (4).

1. Aspek Genetik

$$
\mathrm{Ng}=(60 \% * 4)+(40 \% * 3.5)=3.8
$$

2. Aspek Ransum Pakan

$$
\mathrm{Nr}=(60 \% * 2.5)+(40 \% * 3.5)=2.9
$$

3. Aspek Lingkungan

$$
\mathrm{Nl}=(60 \% * 3.75)+(40 \% * 3.5)=3.65
$$

Tahap akhir dari proses Profile Macthing adalah melakukang perhitungan rangking dengan menjumlahkan nilai total dari tiap aspek menggunakan persamaan (5), Prosentase nilaitotal pada aspek genetik, ransum pakan dan lingkungan adalah sebersar 50\%, 30\% dan 20\%, dapat ditentukan nilai rangking performa produksi burung puyuh dari id puyuh P01 adalah:

Rank $=(50 \% * 3.8)+(30 \% * 2.9)+(20 \% * 3.65)$

$$
=3.5
$$

Jadi nilai perangkingan untuk Puyuh dengan id P01 adalah 3.5.

\section{A. Simpulan}

\section{SimpUlan DAN SARAN}

Kesimpulan yang diperoleh berdasarkan penelitian yang telah dilakukan adalah:

a. Data yang didapatkan dari hasil wawancara dengan pemilik peternakan ada tiga aspek yang dapat digunakan dalam perhitungan profile matching, yaitu aspek genentik, aspek ransum pakan dan aspek lingkungan ketiga aspek tersebut diterapkan kedalam sistem pendukung keputusan performa produksi burung puyuh, dari hasil perhitungan SPK menggunakan metode profile matching didapatkan nilai ranking dari P01 adalah 3.5.

b. Perancangan aplikasi SPK ini dimulai dengan mengolah data yang sudah didapatkan kemudian merancang sebuah DFD sebagai gambaran sistem yang akan buat, Flowchart diagram yang menunjukkan arus dari suatu sistem, dan 
Basis data sebagai tempat intuk menyimpan data-data yang sudah diperoleh. Bahasa pemrograman yang digunakan untuk menerapkan profile matching kedalam sistem pendukung keputusan performa produksi burung puyuh ini menggunakan PHP, Javascript dan HTML.

c. Pengujian beta dilakukan secara objektif dimana sistem pendukung keputusan performa produksi telur puyuh diuji secara langsung ke peternakan Kidung Asmara dan mengisi kuisioner sesuai dengan tanggapan pengguna. Pengguna yang digunakan sebagai sampel sebanyak 2 orang adalah pengelola peternakan tersebut. Hasil yang di dapatkan adalah 2 orang menyatakan setuju pada pertanyan nomor 1 sampai 4, dan sangat setuju pada pertanyaan nomor 5, sementara pada pertanyaan nomor 6 sampai 10 kedua responden menyatakan tidak setuju. Dari hasil tersebut dapat disimpulkan bahwa:

1. Aplikasi yang dibangun dapat membantu proses pengambilan keputusan.

2. Aplikasi yang dibangun dapat mempermudah proses pengambilan keputusan.

3. Aplikasi yang dibangun dapat mempercepat proses pengambilan keputusan.

4. Aplikasi mudah digunakan.

\section{B. Saran}

Berdasarkan analisis dan kesimpulan di atas, beberapa saran yang ingin disampaikan adalah:

a. Sistem ini masih sangat sederhana, maka kedepannya diharapkan bisa menambah cakupan aspek yang lebih luas guna menghasilkan keluaran yang lebih baik.

b. Sistem ini dapat dikembangkan menjadi sistem informasi dimana fitur, fungsi dan kegunaannya akan semakin kompleks.

Sistem ini masih berbasis web, diharapkan kedepannya bisa dijalankan dengan berbasis desktop ataupun mobile application.

\section{DAftar Pustaka}

Abidin, Z. 2002. Meningkatkan Produktivitas Puyuh. (Si Kecil yang Penuh Potensi). Jakarta: Agro Media Pustaka.

Achmanu, Mahi, Muhammad, dan Muharlien. 2015. Pengaruh Bentuk Telur dan Bobot Telur Terhadap Jenis Kelamin, Bobot Tetas dan Lama Tetas Burung Puyuh(Coturnix-Coturnix Japonica). Universitas Brawijaya. Malang.

Ditjennak. 2015. Statistik Peternakan dan Kesehatan Hewan 2015. Jakarta: DITJENNAK Kementrian Pertanian RI.

Jogiyanto. 2001. Analisis dan Desain Sistem Informasi. Yogyakarta: Andi.

Listiyowati, E \& Roospitasari, K. 2009. Beternak Puyuh Secara Komersial. Jakarta: Penebar Swadaya. 
Kusrini. 2007. Konsep dan Aplikasi Sistem Pendukung Keputusan. Yogyakarta: Andi. Sparague, R. H. and Watson H. J. 1993. Decision Support Systems: Putting Theory into Practice.Englewood Clifts, N. J., Prentice Hall.

Turban, E. 2005. Decision Support System and Intelligent System Edisi Bahasa Indonesia. Yogyakarta: Andi.

Turban, Efraim \& Aronson, Jay E. 2001. Decision Support Systems and Intelligent

Systems. $6^{\text {th }}$ edition. Prentice Hall: Upper Saddle River, NJ. 